- This paper directly estimates the deviation in prices between those done within a multinational and those done at arm's length while controlling for firm and destination characteristics.

- We find significant transfer pricing behavior, with prices diverging by $11 \%$.

- Transfer pricing is due primarily to tax havens, not simply low-tax countries.

D During our sample, transfer pricing resulted in a $1 \%$ reduction in French corporate tax revenue. 


\section{Abstract}

This paper analyzes the transfer pricing of multinational firms. We propose a simple framework in which intra-firm prices may systematically deviate from arm's length prices for two motives: i) pricing to market, and ii) tax avoidance. Multinational firms may decide not to avoid taxes if the risk to be sanctioned is high compared to the tax gap. Using detailed French firm-level data on arm's length and intra-firm export prices, we find that both mechanisms are at work. The sensitivity of intra-firm prices to foreign taxes is reinforced once we control for pricing-to-market determinants. Most importantly, we find almost no evidence of tax avoidance if we disregard exports to tax havens. Back-of-theenvelope calculations suggest that tax avoidance through transfer pricing amounts to about $1 \%$ of the total corporate taxes collected by tax authorities in France. The lion's share of this loss is driven by the exports of 450 firms to ten tax havens. As such, it may be possible to achieve significant revenue increases with minimal cost by targeting enforcement.

\section{Keywords}

Transfer pricing, Tax haven, Pricing to market.

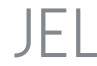

F23, H25, H25, H32.

\section{Working Paper}

\section{CEPI}

CEPII (Centre d'Etudes Prospectives et d'Informations Internationales) is a French institute dedicated to producing independent, policyoriented economic research helpful to understand the international economic environment and challenges in the areas of trade policy, competitiveness, macroeconomics, international finance and growth.
CEPII Working Paper

Contributing to research in international economics

C C CEPII, PARIS, 2014

All rights reserved. Opinions expressed in this publication are those of the author(s) alone.

$\begin{array}{ll}\text { Editorial Director: } & \text { CEPII } \\ \text { Sébastien Jean } & \text { 113, rue de Grenelle } \\ & 75007 \text { Paris } \\ \text { Production: } & +33153685500 \\ \text { Laure Boivin } & \\ \text { No ISSN: } 1293-2574 & \text { Prw.cepii.fr }\end{array}$




\title{
Knocking on Tax Haven's Door: Multinational Firms and Transfer Pricing *
}

\author{
Ronald B. Davies ${ }^{1}$, Julien Martin ${ }^{2}$, Mathieu Parenti ${ }^{3}$, and Farid Toubal ${ }^{4}$ \\ ${ }^{1}$ Department of Economics, University College Dublin, Ireland \\ ${ }^{2}$ Department of Economics, Université du Québec à Montréal, Canada \\ ${ }^{3}$ CORE-UCLouvain and IRES UCLouvain (Belgium), NRU-Higher School of Economics (Russia) \\ ${ }^{4}$ Ecole Normale Supérieure de Cachan, Paris School of Economics and CEPII, France
}

\section{Introduction}

A wealth of empirical evidence finds that, within a multinational enterprise (MNE), reported profits vary systematically with local corporate tax rates. ${ }^{1}$ This may be due to several types of efforts within the firm, including transfer pricing. From the perspective of tax authorities, internal transactions between related parties should be valued at the market price: this is the arm's length principle (see OECD 2012, for details). That said, as described in OECD (2010) there are numerous ways of determining the arm's length price, including the use of comparable prices, and cost-plus methods, among others. Thus, the flexibility in these rules allows firms to choose transfer pricing methodologies which support the use of internal prices which shift profits from high- to low-tax countries. ${ }^{2}$ This is in addition to the potential for outright tax evasion via transfer pricing.

\footnotetext{
${ }^{*}$ We wish to thank Andrew Bernard, Kristian Behrens, Robert Cline, Paola Conconi, Anca Cristea, Meredith Crowley, Lorraine Eden, Peter Egger, Lionel Fontagné, James Hines, Lindsay Oldenski, Bernard Sinclair-Desgagné, Nicholas Sly, and seminar participants at CEPII, the "competitiveness and corporate taxation: impact on multinationals' activities" conference (Banque de France), 2014 EEIT Conference (U. Oregon), ETSG, HEC Montréal, Midwest Meeting (Kansas U.), the "National Institutions in a Globalized World" workshop (Lille), Saint Petersburg, UQAM, and ULB for helpful comments. Financial support was provided by the iCODE Institute (Idex Paris-Saclay) and the FRQSC grant 2015-NP-182781.

${ }^{1}$ See Fuest et al. (2003) for a survey on the impact of taxation on real MNE activity.

${ }^{2}$ An OECD survey of tax authorities reaches the conclusion that "tax administrations see transfer pricing as one of the most significant tax risks they have to manage" (OECD 2012, p.15). Gresik (2001) provides a survey with an emphasis on the transfer pricing literature. A recent meta-analysis by Heckemeyer \& Overesch (2013) shows that transfer pricing and licensing are two important means of shifting profits abroad. Recent theoretical contributions on tax-induced transfer pricing include Behrens et al. (2009), Bernard et al. (2006), and Keuschnigg \& Devereux (2013) which provides a recent model of non-tax-induced transfer pricing, one motivated instead by manipulating managerial incentives. Diewert et al. (2006) gives an overview of the different rationales for manipulating internal prices.
} 
Direct empirical evidence of tax-induced transfer pricing however is scarce. Identifying such a strategy faces two major difficulties. While multinationals' exports are directly observable, detailed information on the prices of products and their modes of transaction whether it is arm's length or intra-firm - is generally not available. Moreover, it is impossible to observe the counterfactual arm's length prices of an intra-firm transaction (see Diewert et al. 2006, for details). Since the arm's length price is not observed, tax authorities have to fix the market price, which raises obvious definitional and methodological issues.

In this paper, we overcome both difficulties. We observe the export prices under each mode (arm's length or intra-firm) at the level of firms, countries, and products. Our econometric methodology moreover allows us to compare the intra-firm price with its corresponding arm's length price. We show that the bulk of tax avoidance comes from a few large firms through exports to a relatively limited number of "tax havens", where the baseline estimates find that intra-firm prices are on average $11 \%$ lower than arm's length prices. ${ }^{3}$ This suggests that, by targeting enforcement efforts, tax authorities may be able to mitigate transfer pricing and raise tax revenues, while keeping enforcement costs low. The granular dimension of tax avoidance should facilitate the implementation of such global enforcement as the one proposed by Zucman (2014).

In order to frame our empirics, we first develop a theoretical model on the determinants of arm's length and intra-firm prices. The model goes beyond the traditional theoretical literature as it takes both tax-induced transfer pricing and pricing-to-market strategies into account. The latter has been receiving increasing attention in the field of international trade. ${ }^{4}$ The model shows that an exporting MNE finds it optimal to deviate from the arm's length prices when it exports to countries with a different level of taxes than its home country. The wedge between the intra-firm price and the arm's length price is a decreasing function of the host tax. We also show that arm's length and intra-firm prices are likely to have a different sensitivity to transport costs, tariffs, and GDP per capita, i.e. variables governing pricing to market. This result suggests that one should be mindful of this difference in sensitivity in the empirical analysis. If one of these variables is significantly correlated with the level of corporate tax rates (something which is true in our data), not allowing coefficients to differ across pricing modes would bias the estimated coefficients.

On the empirical side, we rely on a unique dataset that has detailed information on the intra-firm and arm's length quantities and prices of exported products at the firm-level for almost all French firms exporting in 1999. France is a useful country for this exercise as it exempts foreign income from taxation. Compared with the U.S. and other countries where foreign tax credits and deferral complicate a firm's tax planning problem, the relatively streamlined French system provides a cleaner mapping between tax differences and firm incentives. ${ }^{5}$ Our identification strategy makes use of a set of triadic fixed effects at the level of the firm, product and mode of transaction to control for unobservable determinants of prices specific to firms, products and mode (such as firm productivity). The use of triadic

\footnotetext{
${ }^{3}$ About 25 firms accounts for $50 \%$ of intra-firm trade with the tax havens in our sample.

${ }^{4}$ Examples include Bastos \& Silva (2010), Manova \& Zhang (2012), and Martin (2012).

${ }^{5}$ Bernard et al. (2006) provide a detailed discussion of the complexity of the U.S. tax system.
} 
fixed effects allows us to study the gap between arm's length prices and intra-firm prices which are driven by the characteristics of the destination country. More specifically, we interact an intra-firm trade dummy with a measure of destination countries' corporate taxes to examine whether differences in intra-firm and arm's length prices can be accounted for by the tax differentials across countries. In addition, we control for several pricing-to-market variables identified as important in the trade literature (income, distance, and tariffs) and allow the sensitivity to these variables to differ across modes.

In line with the main theoretical prediction, our estimates suggest that export prices drop with the destination corporate tax rate only for intra-firm transactions. This result is robust once we control for pricing to market. We then show that the effect of taxes is non-linear. Transfer pricing is essentially directed to countries with very low tax rates. Interestingly, low taxes are not the entire story. The bulk of tax avoidance is attributable to the transfer pricing of exports to tax havens. Tax havens not only have low corporate tax rates, but they also provide an overall tax environment that seems to facilitate profit shifting through transfer pricing. ${ }^{6}$ For the ten tax havens in our sample, these additional factors may well differ from one to the other. For example, Ireland and Luxembourg came under fire from the European Commission in 2014 for offering firm-specific tax advantages which amounted to state support. In addition, in our sample, Ireland's "double Irish" system, which allows firms to be incorporated but not tax residents was in full effect (a policy which is due to be phased out beginning in 2015). Switzerland, meanwhile, is well known for its reticence to provide information to other tax authorities, a factor which may aid in tax avoidance. Cyprus had a similar policy up to 2013, when, as part of the bailout it received during the financial crisis, it reversed its policy. Thus, while the phrase "tax haven" is burdened by a negative connotation implying secrecy and lax policy enforcement, we use it with a broader meaning covering a variety of firm-friendly tax policies. Extending our investigation finds that profit shifting through transfer pricing is primarily done by large multinational firms.

A simple exercise suggests that the tax losses driven by the profit shifting of multinational firms to the ten tax havens in our sample amounts to about $1 \%$ of total corporate tax revenues in France. We further show that 450 MNEs account for over 90\% of intra-firm exports to these ten tax havens, implying that a large share of transfer pricing may be curbed by focusing enforcement on a small number of firms.

Although there is a large literature on the impact of international tax differences on the location of profits and firms, the results of which are suggestive of transfer pricing, there is very little evidence of the impact of taxes on transfer prices themselves. ${ }^{7}$ Bartelsman \& Beetsma (2003) use aggregated data on value added across manufacturing sectors in the OECD. They estimate a value added function depending on corporate tax rates and other factors, finding results suggestive of profit shifting via transfer pricing. Clausing (2003) uses price indices for U.S. exports and imports which include separate indices for intra- and extrafirm prices, finding a strong and significant impact of taxes consistent with transfer pricing.

\footnotetext{
${ }^{6}$ Gumpert et al. (2011) provide a discussion of this in the context of an exemption-granting country like France.

${ }^{7}$ For a recent discussion of the former, see Huizinga \& Laeven (2008). Dharmapala \& Riedel (2013) discuss the impact of taxes on firm financing.
} 
Using an approximation of intra-firm trade from firm-level balance sheet data, Overesch (2006) finds that the value of German MNEs' intra-firm trade varies with the difference between the German tax rate and that of the foreign parent/affiliate's location. However, his analysis does not compare the price to an arm's length price. As the arm's length price may also vary with the overseas tax, his result could be due to pricing to market instead of transfer pricing. ${ }^{8}$ Two interesting papers, Vicard (2014) and Cristea \& Nguyen (2014), exploit the panel dimension of firm-level data on French and Danish firms respectively. Both papers tend to provide evidence of transfer pricing. However, they do not observe intra-firm and arm's length prices, but assume intra-firm prices for transactions with countries where a related party is located. As mentioned by Ramondo et al. (2011) and Atalay et al. (2014), most firms with an affiliate in a country do not trade with this affiliate. Furthermore, a firm that exports a product to its affiliates might also well export another product to a third firm in the same country. In our sample of firm-country pairs where we observe positive intra-firm trade, the share of intra-firm trade in a firms' total trade is below $40 \%$ for one fourth of observations. Our empirical tests rely on precise firm-level data on intra-firm and arm's length prices.

Finally, our paper is related to the work of Bernard et al. (2006) who examine how internal prices depend on taxes and tariffs using U.S. firm-level data. Similarly to the papers mentioned above and to our own results, their estimates are consistent with transfer pricing. We depart from this paper along three dimensions. First, and most importantly, we consider the tax haven status as well as tax rates. Since our estimates indicate that internal and arm's length prices deviate most when the destination is a tax haven, this is critical. Second, we examine whether all multinational firms are likely to use transfer pricing to shift profits abroad. ${ }^{9}$ Our findings indicate that the intensity of profit shifting is systematically greater for larger firms. Lastly, our methodology is different: we use French rather than U.S. data, we run price regressions including firm-product-mode fixed effects rather than working with price gaps, and we allow intra-firm and arm's length prices to differ for other reasons than fiscal motives. By using French rather than U.S. data, we avoid the complications in taxation introduced by the U.S. foreign tax credit system. The price regression with individual fixed effects offers a flexible framework to measure whether intra-firm and arm's length prices differ. Finally, accounting for differences in pricing to market between pure exporters and intra-firm exporters is consistent with the theory, and not doing so may bias the results.

The rest of the paper is organized as follows. In Section 2, we present the theoretical model and its predictions for the empirical analysis. In Section 3, we carefully present the data and the estimation sample construction. In Section 4, we present the baseline estimation, extend the results, and provide a quantification exercise estimating the revenue loss for France due to transfer pricing. We conclude in Section 5.

\footnotetext{
${ }^{8}$ Using firm-product level data, Swenson (2001) finds that prices react to taxes and tariffs, however, she is unable to distinguish between intra-firm and arm's length transactions and thus, again, it is not clear whether this is linked to transfer pricing or pricing to market.

${ }^{9}$ Bernard et al. (2006) show that the price wedge between intra-firm and arm's length transactions depends on the size of exporters and the differentiation of products. However, they do not study whether the sensitivity of the price wedge to corporate taxes depends on these characteristics.
} 


\section{Model}

We present a simple model that illustrates how taxes and other factors, such as trade costs or market size, influence the pricing strategies of a firm. The firm produces an intermediate good in its home country at a constant marginal cost $c$ and sells it to its overseas affiliate at a free-on-board price $p_{M N E}^{H}$. For sake of simplicity, we assume the domestic and foreign sales to be separable. ${ }^{10}$ We assume that exports incur an ad-valorem cost $\tau_{v} p_{M N E}^{H}$ such as tariff or insurance and a specific cost $\tau_{f}$, such as the cost of shipping. ${ }^{11}$ These trade costs are specific to the destination market. We assume the production of the final good to be costless. The foreign consumer price is denotes $p_{M N E}^{F}$.

For the determination of the price for the intermediate, we use the popular "concealment cost" approach to modeling transfer pricing. ${ }^{12,13}$ In this, the transfer price $p_{M N E}^{H}$ can differ from the price, $p^{H}$ that would be set by a firm selling to an unaffiliated party, but this incurs a cost $\Phi\left(p_{M N E}^{H}-p^{H}\right)$ where $\Phi$ is defined as follows:

$$
\Phi(x):=\left\{\begin{array}{cll}
\varphi(x)+F & \text { if } & x \neq 0 \\
0 & \text { if } & x=0
\end{array}\right.
$$

where $\varphi($.$) is the variable component of this cost which is continuously differentiable, convex,$ and such that $\varphi(0)=\varphi^{\prime}(0)=0$ with $\varphi^{\prime}(x)>0$. Last, we assume that $\varphi($.$) is an even$ function $\varphi(x)=\varphi(-x) \forall x \in \mathbb{R}$ so that the concealment cost depends upon the price gap only. This concealment cost is generally interpreted in transfer pricing models as the cost to hire accountants to "cook the books" and/or as the fines that the firm would pay if it is caught. We allow these costs to entails a fixed cost $F$ and a variable cost $\varphi($.$) which increases$ marginally with the price wedge. Note that this might vary across countries; for example, if a tax haven makes this concealment relatively easy, then this could reduce the total and marginal cost for a given $x$. The arm's length price is taken as given by the firm and $\Phi$ is the tax-deductible cost that occurs in the home country. As an alternative, we could derive this function along the lines of Becker \& Davies (2014) where, rather than illicit tax avoidance, firms choose their transfer pricing methodologies from a range of legal alternatives. As they show, even when firms are audited with certainty, rendering concealment pointless, their ability to affect government-approved transfer pricing via the choice of methodology results in similar predictions regarding transfer pricing and taxes. However, given the complexity of that model relative to our aims, we maintain the current approach due to its relative transparency.

\footnotetext{
${ }^{10}$ The final good is not imported back to the domestic country.

${ }^{11}$ See for instance Goldberg \& Campa (2010) or Berman et al. (2012).

${ }^{12}$ This approach was initiated by Kant (1988) and forms the predominate method of modeling transfer pricing in theory (eg. Haufler \& Schjelderup 2000) and the empirics (eg. Huizinga \& Laeven 2008).

${ }^{13}$ Ernst \& Young (2012) suggest that prices is one of the issues which receive "the greatest scrutiny" while volumes are not mentioned (p63). However, one can show that our results hold if the tax authority puts enough weight on price deviations relative to the volume that is exported. Specifically, if one assumes that the concealment cost function is $\varphi\left[\left(p_{M N E}^{H}-p^{H}\right) d\left[p_{M N E}^{F}\right]^{\alpha}\right]+F$ with $\alpha \geq 0$ and $\varphi(z)=z^{2}$, our results hold if and only if $\alpha<1 / 2$.
} 
Both countries levy taxes on a territorial basis, where the home tax is $T^{H}$ and the foreign tax is $T^{F}$. This is consistent with the tax-exemption rule for the income earned abroad by French MNEs.

This results in profits given by:

$$
\begin{aligned}
\pi_{M N E} & =\left(1-T^{H}\right)\left(\left(p_{M N E}^{H}-c\right) d\left[p_{M N E}^{F}\right]-\Phi\left[p_{M N E}^{H}-p^{H *}\right]\right) \\
& +\left(1-T^{F}\right)\left(p_{M N E}^{F}-\left(\left(1+\tau_{v}\right) p_{M N E}^{H}+\tau_{f}\right)\right) d\left[p_{M N E}^{F}\right]
\end{aligned}
$$

The price $p^{H *}$, is the arm's length price of a firm selling the product to a third party. To back out this price, one needs to observe two firms with identical characteristics that serve the same market with different modes (eg. the mode is randomly assigned to each firm). We cannot observe this counterfactual in the data. This simple model takes into account that the arm's length price is itself a function of market characteristics. This means that our definition of transfer pricing disentangles variations in market power across countries (through variations in $p^{H *}$ ) from variations in transfer pricing $p_{M N E}^{H}-p^{H *}$.

Profits are maximized by choosing the transfer price $p_{M N E}^{H}$ and the price of the final good $p_{M N E}^{F}$. Assuming that $F=0$ and defining the relative effective tax on foreign-earned profits by $t^{F}=\frac{T^{F}-T^{H}}{1-T^{H}}$, the maximization of (2) results in a first order condition for the transfer price of

$$
\left(1-\left(1-t^{F}\right)\left(1+\tau_{v}\right)\right) d\left[p_{M N E}^{F}\right]=\varphi^{\prime}\left[p_{M N E}^{H}-p^{H *}\right]
$$

where the second-order condition in $p_{M N E}^{H}$ is implied by the convexity of $\varphi$ for any prices $p^{H *}$ and $p_{M N E}^{F}$. Since, $\varphi()$ is even, we have that $\varphi^{\prime}(x)=-\varphi^{\prime}(-x) \forall x \in \mathbb{R}$. Using that $\varphi^{\prime}(0)=0$, the above equation implies that the direction of profit shifting is determined by the sign of the left-hand side. Assuming that $\mathcal{T} \equiv\left(1-t^{F}\right)\left(1+\tau_{v}\right)>1$ implies that a firm sets $p_{M N E}^{H *}<p^{H *}$ in order to shift profits to the foreign country. This happens whenever the corporate tax abroad is lower than at home $\left(t^{F}<0\right)$. This is a standard result in the transfer pricing literature. We shall stress that the multiplicative trade costs (e.g. tariffs) are also a motive for transfer pricing and that the two effects interact with one another. We summarize this result in the following proposition:

Proposition 2.1. The level of corporate taxes and multiplicative trade costs determine the direction of the deviation of intra-firm prices from arm's length prices. Free-on-board intrafirm prices are lower than arm's length prices in destinations with lower corporate taxes or high tariffs.

Equation (2) shows that the price gap is also positively correlated with the volume $d\left[p_{M N E}^{F}\right]$ that is exported. This occurs because, although a non-zero price wedge increases per-unit after-tax profits the marginal concealment cost is independent of quantity. The deviation from the arm's length price is increasing in firm size, presuming that consistent with the data that larger firms export more. The first order condition in equation (2) holds 
for any value of $c$. Therefore, the transfer pricing strategies of multinationals with different marginal costs differ if they ship different volumes $d\left[p_{M N E}^{F}\right]$.

Proposition 2.2. Large volumes of intra-firm trade come with large deviations of intra-firm prices with respect to arm's length prices.

Remark 1 (inaction band): The above propositions show that a multinational firm finds it optimal to shift profits abroad when $F=0$ and taxes differ even marginally. The fixed component in the concealment cost function however, implies that there is an inaction band. In other words, we should not expect firms to shift profits abroad when the corporate tax (tariff) differential is small.

Note that (2) does not necessarily imply that the magnitude of transfer pricing increases in the tax differential. To see this, consider the first order condition for the final good's price:

$$
\left(p_{M N E}^{H}-c+\left(1-t^{F}\right)\left(p_{M N E}^{F}-\left(\left(1+\tau_{v}\right) p_{M N E}^{H}+\tau_{f}\right)\right)\right) d^{\prime}\left[p_{M N E}^{F}\right]+\left(1-t^{F}\right) d\left[p_{M N E}^{F}\right]=0
$$

We assume, as is standard, that the demand is not "too convex" to guarantee that the second-order condition holds. Rearranging equation (3) leads to the following system of equations which define $p_{M N E}^{H *}$ and $p_{M N E}^{F *}$ :

$$
\begin{gathered}
(1-\mathcal{T}) d\left[p_{M N E}^{F *}\right]=\varphi^{\prime}\left[p_{M N E}^{H *}-p^{H *}\right] \\
p_{M N E}^{F *}=\frac{1}{1-\mathcal{E}^{-1}\left[p_{M N E}^{F *}\right]}\left[\frac{(\mathcal{T}-1) p_{M N E}^{H *}+c}{1-t^{F}}+\tau_{f}\right] \quad \text { where } \quad \mathcal{E}[z]=-\frac{d^{\prime}[z] z}{d[z]}
\end{gathered}
$$

Now, let us assume that $t^{F}<0$ and $\tau_{v}=0$. We find $\mathcal{T}=1-t^{F}>1$ which implies, by proposition 1 , that $p_{M N E}^{H *}<p^{H *}$. In this simple example, we see that a change in $t^{F}$ has two opposing effects on internal prices. First, equation (4) shows that a decrease in $t^{F}$ leads to a decrease in $p_{M N E}^{H *}$ keeping $p_{M N E}^{F *}$ constant, i.e. more transfer pricing. This change is larger when the output is large and the penalty function is not "too convex". However, equation (5) shows that, as the drop in the foreign tax lowers after-tax costs, the firm will adjust $p_{M N E}^{F *}$, and hence the output, when changing $p_{M N E}^{H *}$. The magnitude of this adjustment depends crucially on the demand price-elasticity $\mathcal{E}\left[p_{M N E}^{F *}\right]$ and on how much the firm passes onto its final price changes in its free-on-board price.

There is therefore no reason to expect that a decrease in $t^{F}$ (and thus an increase in $\mathcal{T}$ ) impacts monotonically the price gap. It is standard however to dismiss the output adjustment (see Cristea \& Nguyen (2014) for a detailed discussion and simulations under iso-elastic demand). Equation (5) offers an additional rationale to this assumption if we assume that $\frac{d \mathcal{E}}{d z}>0$. This restriction is verified if demand is more elastic at high prices which is both intuitive and a commonly used assumption in models of monopolistic competition with variable mark-ups. In this event, a relative change in the free-on-board price leads to a smaller 
relative change in the final price and thereby a lower change in output. We thus find it reasonable to expect that, as is commonly assumed in the transfer pricing literature, the price gap increases in $\mathcal{T}$. While a within-market comparison of the price gap between multinationals and arm's length exporters would not be evidence of transfer pricing, the theory suggests to identify transfer pricing by comparing the price-gap across different markets.

We now turn to the importance of market characteristics. Although the firm takes the arm's length price $p^{H}$ as given, this too is determined as a function of local characteristics since, as is well established, the free-on-board price of exports will vary with destination specifics. Thus, in order to accurately compare the differences between intra- and extra-firm prices and how they vary with destination characteristics, it is necessary to consider the relative responses of $p_{M N E}^{H}$ and $p^{H}$. We show below that even under the commonly used assumption of CES preferences, market characteristics may impact differently $p_{M N E}^{H}$ and $p^{H}$.

The profits of a pure exporter, which both produces the intermediate and converts it into the final good at home, can be written as:

$$
\max _{p^{H}} \pi=\left(p^{H}-c\right) d\left[\left(1+\tau_{v}\right) p^{H}+\tau_{f}\right]
$$

where the final consumer pays the cost-including-freight price $\left(1+\tau_{v}\right) p^{H}+\tau_{f}$. With iso-elastic demand, the demand curve can be written as:

$$
d\left[\left(1+\tau_{v}\right) p^{H}+\tau_{f}\right]=A\left(\left(1+\tau_{v}\right) p^{H}+\tau_{f}\right)^{-\eta}
$$

where $A$ is a demand shifter which depends on the market structure and $\eta$ is the constant price-elasticity of demand. ${ }^{14}$

The in order to maximize profits, the exporter sets a free-on-board price equal to:

$$
p^{H *}=\frac{\eta}{\eta-1}\left(c+\frac{\tau_{f}}{\eta\left(1+\tau_{v}\right)}\right)
$$

which is increasing in trade costs whenever $\tau_{f}>0$. Since transport costs increase with distance, fob prices are expected to increase with distance as found by Bastos \& Silva (2010), Manova \& Zhang (2012), Martin (2012). Since distribution costs are an increasing function of foreign wages, we expect fob prices to increase with GDP per capita as found by Simonovska (2010). Thus, exporters price to market, resulting in an arm's length price that varies by destination. Note, however, that as all revenues and costs are incurred at home, this price is independent of taxes.

Returning to the MNE's first order conditions, with iso-elastic demand, (4) and (5)

\footnotetext{
${ }^{14}$ In a CES model of monopolistic competition, this constant is $\frac{y}{\mathcal{P}^{1-\eta}}$ where $y$ stands for income, $\mathcal{P}$ is a price-index of all varieties supplied in the market and $\eta$ can be interpreted as the elasticity of substitution between varieties.
} 
become:

$$
\begin{gathered}
(1-\mathcal{T}) A\left(p_{M N E}^{F *}\right)^{-\eta}=\varphi^{\prime}\left[p_{M N E}^{H *}-\frac{\eta}{\eta-1}\left(c+\frac{\tau_{f}}{\eta\left(1+\tau_{v}\right)}\right)\right] \\
p_{M N E}^{F *}=\frac{\eta}{\eta-1}\left[\frac{(\mathcal{T}-1) p_{M N E}^{H *}+c}{1-t^{F}}+\tau_{f}\right]
\end{gathered}
$$

which determine both $p_{M N E}^{H *}$ and $p_{M N E}^{F *}$ implicitely as functions of $\tau_{f}$. Clearly, the elasticity of $p_{M N E}^{H *}$ with respect to $\tau_{f}$ is generally different from the elasticity of $p^{H *}$ and without more structure on the model, one can not infer whether the price gap is magnified or reduced when, let's say, distance or GDP per capita increases.

Remark 2: The sensitivity of arm's length and intra-firm prices with respect to distance and GDP per capita generally differs.

Thus, the size of the price wedge will vary according to destinations. Failure to account for this can potentially result in misleading estimates of the impact of taxes on the difference between intra-and extra-firm prices.

This theoretic exercise yields a set of predictions for us to take to the data. First, a higher destination tax should lower the intra-firm price but have no effect on arm's length prices. Second, prices should be an increasing function of specific trade costs (such as distance) and destination income but a declining function of ad valorem trade costs (such as tariffs). Finally, there should in general be differences in the impacts of these three variables on arm's length prices and transfer prices. In the next section, we describe the data and methodology used to test these predictions.

\section{Data and identification strategy}

\subsection{Data description}

To investigate the factors driving transfer pricing, we use detailed information on intra-firm and arm's length export prices for a set of French firms in 1999. In order to construct our estimation sample, using a unique firm identifier, we combined three datasets that have detailed information on firm-level exports values and quantities of 8-digit product categories by destination, data on MNE status, and information on whether a transaction is intra-firm or arm's length. We merge these datasets with information on country-level characteristics such as the level of corporate tax rate, distance, tariff or per-capita income.

Firm-level data. Our first dataset comes from the French Customs which reports the free-on-board values and quantities of exports by firm, 8-digit CN product category, and destination. We combine the value and quantity of export for firm, product CN8, and destination triad to construct the destination- and firm-specific free-on-board unit values our proxy for the price a firm charges for that good in a given market. 
This dataset, however, does not provide information on the mode of exports, that is, whether a transaction is intra-firm or at arm's length. We obtain this information from a confidential 1999 survey of MNEs in France (both French and foreign-owned) which comes from the INSEE. ${ }^{15}$ The survey was addressed to all such MNEs with trade worth more than 1 million Euro and covers firms providing $87 \%$ of the French total industrial product exports. ${ }^{16}$ The INSEE survey provides a detailed geographical breakdown of French MNEs' export values and quantities at product level (HS4) and their exporting modes - through outside suppliers and/or related parties. Using a CN8-HS4 correspondence table, we match each 8-digit product category to their corresponding HS4 category. When the INSEE indicates that an HS4 category has a share of intra-firm exports exceeding 98\%, we classify all the corresponding CN8 exports by MNEs to be intra-firm transactions. ${ }^{17}$ If the share is zero, we classify the CN8 codes as arm's length. When the share is positive but below $98 \%$, we drop this firm's observations within this destination-HS4 dyad, observations which amount to roughly $12.6 \%$ of French exports. We assume for non-MNEs that all exports are done at arm's length and are done through unrelated parties.

Finally, we use information from LIFI, a French-firm level dataset on financial linkages between firms. This is used to determine whether a firm in the French customs data is a MNE and, if so, its nationality and the country locations of their related parties. As this identifies some firms in the French customs data as MNEs but for which we do not have the INSEE data, we drop those observations as we cannot know whether the transaction is intrafirm or arm-length. ${ }^{18}$ We also eliminate the observations of state-owned firms as these firms might have a different price setting mechanism. ${ }^{19}$ LIFI is also interesting because it provides the countries in which the affiliates of firms located in France are themselves located.

This then leaves us with information at the firm, NC8 product, country, and exporting mode level. Once merged with country characteristics, there are 735,064 observations in our unbalanced baseline sample. ${ }^{20}$ Our cross section is composed by 67,312 firms, 5,482 products and 45 countries. About $9.2 \%$ of the total number of observations are intra-firm prices. It is worth emphasizing that most of the prices set by MNEs are not intra-firm prices. In this sample, only $15.6 \%$ of the prices set by MNEs are intra-firm prices. Another interesting fact is that, in our data, one third of multinational firms do not report intra-firm trade in countries where they have affiliates (or a headquarter) according to LIFI. A last fact pertains to the likelihood that we observe both arm's length and intra-firm trade for a multinational firm exporting to a given country. To study this point, we restrict to the sample of firm-destination pairs that feature intra-firm exports. Since firms make part of

\footnotetext{
${ }^{15}$ Échanges internationaux intra-groupe.

${ }^{16}$ www.insee.fr/fr/ffc/docs_ffc/IP936.pdf, INSEE WP 936, Table 1.

${ }^{17}$ Changing this threshold does not change the qualitative results of our empirical analysis.

${ }^{18}$ We lose 605 firms amounting to dropping $2.5 \%$ of the value of French exports.

${ }^{19}$ They account for about $1.7 \%$ of French exports.

${ }^{20}$ We lose information on about $10 \%$ of the French export value when merging the dataset with the tax rates data. We also lose an additional $2.3 \%$ of the export value when merging the data with info on tariffs. The tariffs data are not available for 20 countries of the original sample of 65 countries. Reproducing the estimations without the tariffs variable leads to qualitatively similar results.
} 
their export to these countries intra-firm, we can be certain that the firm has a related party in the destination country. Among these pairs there are firms selling all their exports intrafirm while other firms may export to the country through the two modes. In this sample, the median share of intra-firm trade is $98 \%$. This means that conditional on exporting intrafirm to a country, the median firms export almost entirely intra-firm. This figure, however, hides large variation. In particular, we find that for one fourth of product-country pairs, the share of intra-firm trade is at most $40 \%$. Said differently, even if a firm exports intra-firm to a country, in $25 \%$ of cases, the share of intra-firm exports to the country is below $40 \%$. These facts confirm the usefulness of having information on intra-firm and arm's length transactions. They also show the caveats of databases that only report information on the presence of related parties in the destination country.

Tax and Tax havens data. In our model, the equilibrium is where the marginal savings from reducing tariff and tax payments equals the marginal cost of transfer pricing. Thus, the most appropriate tax measure is the effective marginal tax rate (EMTR) on income as this represents the tax savings from shifting one Euro of income. If taxes are flat, then the EMTR equals the effective average tax rate (EATR). However, if taxes are progressive (as is typically the case), then the EATR will understate the tax savings from transfer pricing. In our baseline results, we use the EMTR from Loretz (2008). In robustness checks, we instead use the EATR and the top statutory corporate tax rate (both from Loretz (2008)) and find qualitatively identical results. In the baseline estimation, we used the EMTR reported in 1998 or 1997 (whichever is closer) when the data for 1999 were missing. ${ }^{21}$ An important aspect of these tax rate measures is that they are constructed from statutory tax policies, but unlike the headline tax rate, accounts for factors such as the tax offsets from capital expenditures (see Loretz (2008) for details). As such, EMRT or EATR are exogenous to firm decisions, something which would not be the case if we used firm accounting data to construct firm-specific taxes.

As seen in table 5 in the appendix, the effective average and marginal tax rates vary considerably across countries. In our estimation sample, the EMTR ranges from $0 \%$ in Bahamas to about $46 \%$ in the Russian Federation. Of large concern in policy circles is the use of investment in tax havens in aggressive tax planning. This is particularly the case for countries such as France or Germany that exempt foreign income from taxation. ${ }^{22} \mathrm{We}$ therefore use additional information on tax havens. Our definition follows Hines \& Rice (1994) which has been recently used by Dharmapala \& Hines (2009). A tax haven is as a location with low corporate tax rates, banking and business secrecy, advance communication facilities and self-promotion as an offshore financial center ((Hines \& Rice 1994), Appendix 1 p. 175). Compared to the list of Tax Havens produced by the OECD (2000), the approach of Dharmapala \& Hines (2009) identifies a number of additional tax havens such as Switzer-

\footnotetext{
${ }^{21}$ Notice that the 37 of 45 countries in our sample share a Bilateral Tax Treaty with France. Controlling for the existence of treaties (and interacting with the intra-firm dummy) does not change the results and indeed, we find little impact of tax treaties on transfer pricing.

${ }^{22}$ See the recent paper by Gumpert et al. (2011), who considers this issue for a large sample of German MNEs.
} 
land. In our estimation sample, the Bahamas, Bermuda, Cayman Islands, Cyprus, Hong Kong, Ireland, Luxembourg, Malta, Singapore and Switzerland are classified as tax havens. Approximately $41 \%$ of firms export to these countries and these exports account for roughly $11 \%$ of the total number of observations.

Pricing to market data. As discussed above, firms adjust their prices to the characteristics of the destination market. The empirical literature has identified two main regularities on firms' pricing to market behavior, namely, firms charge higher prices when the destination if further away and when the destination is wealthier (eg. Bastos \& Silva 2010, Manova \& Zhang 2012, Martin 2012). Berman et al. (2012) have shown that small and large firms may react differently to trade costs depending on their size and productivity. In our model, we show that these factors may impact intra-firm prices differently from arm's length prices. Furthermore, as these market characteristics are correlated to the level of corporate tax rate, it is crucial to control for them. We therefore use data on per capita GDP (measured in US dollars) from the Internal Financial Statistics of the IMF to control for the level of country specific income. As measures of trade costs, we use the bilateral distance variable (which is the population weighted average distance between countries' main cities in kilometers) which is taken from CEPII database (Mayer \& Zignago 2006) and also use information from TRAINS on tariffs faced by French exporters developed by the WITS (UNCTAD). In our data, distance and per capita GDP are both significantly and negatively correlated with both the effective tax rates and tax haven status, suggesting that their omission could bias our results.

\subsection{Identification strategy}

Testing the main propositions of our model requires estimating the effect of the tax variables, the EMTR and/or tax haven, on the differential between the intra-firm price of a specific product in a country and its corresponding arm's length price. Our empirical model includes a set of triadic fixed effects at the level of firm, product and export mode. The use of triadic fixed effects allows us to compare the gap between the arm's length price and the intra-firm price across countries. These fixed effects also account for a wide set of attributes of the transactions at the level of the firm, product, and exporting mode that might also account for the levels of the price differential (Bernard et al. 2006). In our empirical estimation, we make use of an interaction term between the tax variables and an indicator of the exporting mode that is equal to 1 if the transaction is intra-firm and 0 if it is at arm's length. Given the set of controls that we discuss below, the estimated interaction coefficients give an indication of the price differential that is due to transfer pricing. ${ }^{23}$ As we shall show later on, we use destination fixed effects in some specifications to control for destination-specific heterogeneity.

\footnotetext{
${ }^{23}$ Our identification strategy implies that the deviation from the arm's length price in itself is not evidence of transfer pricing. It is an evidence when the gap between the arm's length price and the intra-firm price is significantly related to the tax differential across countries.
} 
The empirical strategy involves estimating the following model:

$$
\begin{aligned}
p_{f p m c} & =\alpha_{1} \text { Intra }_{f p m c}+\alpha_{2} \text { Tax }_{c}+\alpha_{3} \text { Tax }_{c} \times \text { Intra }_{f p m c} \\
& +\alpha_{4} \text { TaxHaven }_{c}+\alpha_{5} \text { TaxHaven }_{c} \times \text { Intra }_{f p m c} \\
& +\gamma_{1} X_{c}+\gamma_{2} X_{c} \times \text { Intra }_{f p m c}+\mu_{f p m}+\epsilon_{f p m c}
\end{aligned}
$$

where $p_{f p m c}$ is the export price charged by firm $f$ for product $p$ in country $c$ under the export mode $m$. Tax is a variable that captures the level of tax in the destination country. Our primary measure is based on the EMTR, defined as $\operatorname{Tax}_{c}=\log \left(1-\tau_{c}\right)$, with $\tau_{c}$ being the EMTR in country $c .{ }^{24}$ Our second measure, TaxHaven ${ }_{c}$, is a dummy variable that takes the value of one if the country is on the tax haven list of Hines \& Rice (1994). These are both also interacted with Intra $_{f p m c}$, a dummy variable that takes the value of one if the export mode is intra-firm and zero otherwise. Since we expect the price wedge to be increasing in the amount of profits retained by the firm (i.e. $\operatorname{Tax}_{c}=\log \left(1-\tau_{c}\right)$ is larger or the country is a tax haven), we anticipate both of these interactions to be negative (i.e. a larger absolute value difference between the intra-firm and arm's length prices).

The term $\mu_{f p m}$ is a comprehensive set of firm-product-mode fixed effects. Notice that it is no longer possible to estimate the direct effect of the export mode because of the triadic fixed effects. $X_{c}$ is a vector of country specific variables that includes the logarithm of distance, tariffs, and the logarithm of GDP per capita. We interact these variables with the intra-firm transaction dummy as the pricing behavior of firms is also affected by bilateral trade costs and income in the destination market and might also vary across the export modes. As the prices might also be influenced by the market structure and the intensity of competition in the foreign market, and since these characteristics are unobservable, we introduce a set of country fixed effects in some specifications. Finally, $\epsilon_{f p m c}$ is the disturbance term. The standard errors are allowed to be adjusted for clustering at the country-level to account for heteroskedasticity and non-independence across the repeated observations within countries.

Table 1 gives the summary statistics.

\section{Results}

Baseline Results. According to the theoretical predictions the average internal price should be lower than the arm's length price in a country with lower marginal effective tax rates. The estimates are reported in Table 2. Overall, the specifications explain from about $87 \%$ of the variation of the log level of export prices as suggested by the adjusted $R^{2}$. The estimates using the EATR variable are reported in Table 6 in the Appendix.

In column (1), we do not find a statistically significant effect of the effective marginal tax rate on the level of arm's length prices. We do, however, find a negative and significant interaction coefficient between the corporate tax and the intra-firm dummy, i.e. internal export prices are relatively lower than arm's length prices in destinations with lower corporate

\footnotetext{
${ }^{24}$ We also use the EATR variable as an alternative definition of the tax rate.
} 
Table 1: Summary statistics

\begin{tabular}{|c|c|c|c|}
\hline Variable & Nature & Mean & Std. Dev. \\
\hline$p_{\text {fpmc }}$ & $(\log )$ & 3.09 & 1.799 \\
\hline Intra $a_{f p m c}$ & $0 / 1$ & 0.092 & 0.288 \\
\hline$\left(1-\tau_{c}\right)(\mathrm{EMTR})$ & $(\log )$ & -0.353 & 0.095 \\
\hline$\left(1-\tau_{c}\right)(\mathrm{EATR})$ & $(\log )$ & -0.383 & 0.091 \\
\hline Tax Haven $_{c}$ & $0 / 1$ & 0.107 & 0.308 \\
\hline Tarif $f_{c}$ & Continuous & 0.270 & 0.739 \\
\hline Distance $_{c}$ & $(\log )$ & 6.986 & 0.865 \\
\hline Per Capita $G D P_{c}$ & $(\log )$ & 9.976 & 0.569 \\
\hline \multicolumn{4}{|l|}{ Intra $_{f p m c} \times:$} \\
\hline$\left(1-\tau_{c}\right)($ EMTR $)$ & & -0.032 & 0.105 \\
\hline$\left(1-\tau_{c}\right)(\mathrm{EATR})$ & & -0.035 & 0.113 \\
\hline TaxHaven $_{c}$ & & 0.007 & 0.083 \\
\hline Tarif $f_{c}$ & & 0.030 & 0.262 \\
\hline Distance $_{c}$ & & 0.653 & 2.073 \\
\hline Per Capita $G D P_{c}$ & & 0.905 & 2.857 \\
\hline Observations & & 735,064 & \\
\hline
\end{tabular}

tax rate. A ten percent decrease in the effective average tax rate leads to a reduction of intrafirm prices by $1.9 \%$ ( $2.2 \%$ using the EATR variable).

In column (2), we control for other country characteristics that might influence the pricing behavior of the firm. Nevertheless, we continue to find comparable results, namely that taxes influence internal prices but not those between unrelated parties. If anything, the estimated impact is slightly larger, suggesting a slight bias when they are excluded. In line with the prediction of our model, we find a positive impact of per-capita GDP on the level of prices. A ten percent increase in per capita GDP raises the export prices by $0.6 \%$. We find however a negative and statistically significant interaction coefficient between the per capita GDP and the intra-firm mode variables. This suggests a slightly lower impact of per-capita GDP on internal prices which may make sense if internal trade includes a larger share of intermediate goods which are not directly sold to overseas customers. Turning to the trade costs variables, in line with the prediction of our model we find a positive effect of distance on export prices. A ten percent increase in distance raises the export prices by $0.8 \%$. As an example, given the distances between France and the countries in our sample, the export prices are on average $0.8 \%$ higher in the Netherlands as compared to Belgium. The effect of distance on internal export prices is lower. Concerning the tariff variable, the effect on arm's length prices is not significant. In other words, there is no evidence of dumping by French arm's length exporters. This might be due to the low cross-country variation in the tariff variable as most of the transactions are observed in countries that are member of the European Union. ${ }^{25}$

\footnotetext{
${ }^{25}$ About $90 \%$ of the observation concerns a transaction toward an E.U. country.
} 
Table 2: Baseline regression Effective Marginal Tax Rate, All firms

\begin{tabular}{|c|c|c|c|c|c|c|}
\hline & \multicolumn{6}{|c|}{ Dependent variables: Export price } \\
\hline & (1) & $(2)$ & (3) & $(4)$ & $(5)$ & (6) \\
\hline$\left(1-\tau_{c}\right)$ & $\begin{array}{c}0.10 \\
(0.755)\end{array}$ & $\begin{array}{c}0.12 \\
(0.870)\end{array}$ & & $\begin{array}{c}-0.01 \\
(-0.137)\end{array}$ & $\begin{array}{c}-0.03 \\
(-0.367)\end{array}$ & \\
\hline$-\times \operatorname{Intra}_{f p m c}$ & $\begin{array}{l}-0.19^{* *} \\
(-2.109)\end{array}$ & $\begin{array}{c}-0.20^{*} \\
(-1.932)\end{array}$ & & $\begin{array}{c}-0.10 \\
(-1.451)\end{array}$ & $\begin{array}{c}-0.05 \\
(-1.056)\end{array}$ & $\begin{array}{c}-0.08 \\
(-1.205)\end{array}$ \\
\hline TaxHaven $_{c}$ & & & $\begin{array}{c}0.11 \\
(1.574)\end{array}$ & $\begin{array}{c}0.12 \\
(1.555)\end{array}$ & & \\
\hline$-\times \operatorname{Intra} a_{f p m c}$ & & & $\begin{array}{l}-0.11^{* *} \\
(-2.686)\end{array}$ & $\begin{array}{l}-0.09^{* *} \\
(-2.365)\end{array}$ & & $\begin{array}{l}-0.09^{* * *} \\
(-2.843)\end{array}$ \\
\hline Per Capita $G D P_{c}$ & & $\begin{array}{l}0.06^{* *} \\
(2.128)\end{array}$ & $\begin{array}{c}0.04 \\
(1.544)\end{array}$ & $\begin{array}{c}0.04 \\
(1.487)\end{array}$ & $\begin{array}{c}0.04 \\
(1.568)\end{array}$ & \\
\hline$-\times \operatorname{Intra}_{f p m c}$ & & $\begin{array}{l}-0.03^{* *} \\
(-2.620)\end{array}$ & $\begin{array}{c}-0.01 \\
(-1.108)\end{array}$ & $\begin{array}{c}-0.01 \\
(-1.187)\end{array}$ & $\begin{array}{l}-0.02^{*} \\
(-1.726)\end{array}$ & $\begin{array}{c}-0.00 \\
(-0.404)\end{array}$ \\
\hline Distance $_{c}$ & & $\begin{array}{l}0.08^{* * *} \\
(2.919)\end{array}$ & $\begin{array}{l}0.08^{* * *} \\
(3.631)\end{array}$ & $\begin{array}{l}0.08^{* * *} \\
(3.652)\end{array}$ & $\begin{array}{l}0.11^{* * *} \\
(4.288)\end{array}$ & \\
\hline$-\times \operatorname{Intra}_{f p m c}$ & & $\begin{array}{l}-0.04^{* * *} \\
(-2.855)\end{array}$ & $\begin{array}{l}-0.05^{* * *} \\
(-4.811)\end{array}$ & $\begin{array}{l}-0.05^{* * *} \\
(-4.518)\end{array}$ & $\begin{array}{l}-0.06^{* * *} \\
(-4.974)\end{array}$ & $\begin{array}{l}-0.05^{* * *} \\
(-4.178)\end{array}$ \\
\hline Tarif $f_{c}$ & & $\begin{array}{c}0.03 \\
(1.052)\end{array}$ & $\begin{array}{c}0.03 \\
(1.122)\end{array}$ & $\begin{array}{c}0.03 \\
(1.158)\end{array}$ & $\begin{array}{c}0.01 \\
(0.418)\end{array}$ & \\
\hline$-\times \operatorname{Intra}_{f p m c}$ & & $\begin{array}{c}-0.03^{*} \\
(-1.995)\end{array}$ & $\begin{array}{l}-0.03^{* *} \\
(-2.617)\end{array}$ & $\begin{array}{l}-0.03^{* *} \\
(-2.426)\end{array}$ & $\begin{array}{c}-0.02 \\
(-1.616)\end{array}$ & $\begin{array}{l}-0.03^{* * *} \\
(-3.138)\end{array}$ \\
\hline Sample & Full & Full & Full & Full & w.o Tax H. & Full \\
\hline Country FE & No & No & No & No & No & Yes \\
\hline Firm-Prod.-Mode FE & Yes & Yes & Yes & Yes & Yes & Yes \\
\hline $\begin{array}{l}\text { Observations } \\
\text { Adj. } R^{2}\end{array}$ & $\begin{array}{c}756,332 \\
0.862\end{array}$ & $\begin{array}{c}735,064 \\
0.865\end{array}$ & $\begin{array}{c}735,064 \\
0.865\end{array}$ & $\begin{array}{c}735,064 \\
0.865\end{array}$ & $\begin{array}{c}657,117 \\
0.870\end{array}$ & $\begin{array}{c}735,064 \\
0.866\end{array}$ \\
\hline
\end{tabular}

Note: This table investigates the impact of effective taxe rate, GDP per capita, distance, tariffs, and tax haven dummy on intra-firm and arm-length export prices. Effective tax rates are transformed as follows: $(\log (1-\tau))$. We use the effective marginal tax rate here. All regressions include firm-product-exporting mode fixed effects. The last column further includes country fixed effects. In column (5) we restrict the sample to countries not classified as tax havens. Robust standard errors clustered by destination are computed. Corresponding t-statistics are reported in parentheses. Significance levels: ${ }^{*} p<0.1,{ }^{* *} p<0.05$, and ${ }^{* * *} p<0.01$.

However, intra-firm prices are significantly smaller that arm's length prices in high-tariff countries, suggesting that firms choose to undervalue their exports to pay less tariffs.

In column (3), we replace our EMTR variable with a dummy variable equal to one if the destination is a tax haven. As tax havens not only have low taxes but often provide 
other mechanisms that facilitate profit shifting (such as the limited exchange of information between tax authorities), one might expect that internal prices differ markedly in these nations. The results are striking. The interaction between the tax haven dummy variable and its interaction with the intra-firm export mode is significant and estimated with a large degree of precision. We do not find a significant effect of the tax haven dummy variable on the arm's length price. This result suggests that arm's length export prices are the same regardless of whether or not the destination is a tax haven. The interaction between the tax haven and the export mode dummy variables is significantly negative, indicating that the average internal export price for a tax haven is about $11 \%$ lower than the comparable arm's length price. This suggests that the tax havens are playing a major role in the transfer pricing strategies of firms.

This finding remains robust in column (4) as we include the effective marginal tax rates and its interaction term with the export mode, where we find the intra-firm export prices to be about $9 \%$ lower than arm's length prices in tax haven destinations even when tax rates do not differ. Notice that the coefficient of the interaction term that involves the EMTR, is smaller and insignificant once we control for the tax havens. As tax havens tend to have low taxes, this suggests that the results in column (2) were biased due to failure to control for tax haven status. Further, it highlights the important difference between having low taxes and having other policies that make tax planning easier. Indeed, the OECD (2013)'s Action Plan on Base Erosion and Profit Shifting makes precisely such a distinction. ${ }^{26}$

In column (5), we investigate the importance of tax havens further by excluding them from the analysis. Compared to column (2), the coefficient of the interaction term that involves the effective tax rate is about four times lower and becomes insignificant, again suggesting that the bulk of the impacts in column (2) were coming from the tax havens.

Finally, column (6) includes a set of destination specific dummy variables. Introducing country fixed effects does not allow us to estimate the direct effect of the country specific variables (including the tax rate and tax haven status). This, however, comes with the benefit of controlling for other destination characteristics. As can be seen, the tax rate interaction remains insignificant. Nevertheless, the tax haven interaction is virtually unchanged in magnitude and becomes even more significant. Thus, even after including destination fixed effects we find evidence of tax-induced transfer pricing which is most evident in tax haven countries. $^{27}$

Non-linear tax effects. To this point, we have investigated the average effect of tax rates on the export price differential. We find evidence of transfer pricing, but only in tax haven countries which are characterized by with very low tax rates. Our results suggest therefore

\footnotetext{
${ }^{26}$ The firms might also operate in tax havens and non-tax havens countries. We also drop the firms that exports in tax havens internally. We don't find a significant tax effect. This suggests that there is no substitution effects. The transfer pricing strategy is not used by firms that do not export to tax havens, while firms that exports to tax havens have lower prices in countries with lower tax rates.

${ }^{27}$ We also investigate whether we find similar effects using firms that sell both arm's length and intra-firm and those that do only intra-firm trade. The results are qualitatively similar. They are available upon request.
} 
a non-linearity of the tax rates on the price differential. We examine this effect further by running a regression using, instead of the EMTR, a set of dummy variables indicating the decile in which a country's EMTR falls. We choose the $9^{\text {th }}$ decile as a benchmark. This decile is composed by 5 countries which have roughly the same effective marginal tax rate as France and where, in theory, internal and arm's length prices should be the same. The first decile includes countries with the lowest effective marginal corporate tax rates. It includes Bahamas, Hong-Kong, Ireland, Slovenia, and South Africa. ${ }^{28}$ The $10^{\text {th }}$ decile includes Argentina, Germany, Japan, and Poland which are the countries with the highest effective marginal corporate tax rates in our sample.

The estimated coefficients of these interaction terms are shown in Figure $1{ }^{29}$ Each dot corresponds to the interaction coefficient between the effective average tax rate and the intra-firm export mode dummy variable. We also display the confidence intervals at the $10 \%$ level. The estimated effects are quite heterogeneous. Along the first remark of the theoretical model, we observe an inaction band when the tax differential is not too large. The point estimate of the interaction effect is however negative and significant only for the countries in the first two deciles. This indicates that our results are very heavily driven by the lowest tax countries, four of which are also classified as tax havens (Ireland, Switzerland, Honk-Kong and the Bahamas).

Additional results. A relevant concern that has been raised in the literature studying the effects of transfer pricing is the differing abilities of firms to engage in transfer pricing (Bernard, et al 2006). In our model, firms with greater size are expected to have larger price differentials. In columns (1) and (2) of Table 3, we split the sample according to the size of the MNEs measured by their total exports. ${ }^{30}$ In the first column, we drop MNEs below the $75^{\text {th }}$ percentile of the distribution of multinationals firm size, and thus keep large MNEs and all pure exporters. In column (2), we drop observations of MNEs above the $25^{\text {th }}$ percentile, retaining only small MNEs and all pure exporters. Looking at the corporate tax and the tax haven interactions with the intra-firm trade dummy, we find significance for tax havens only for the large firms. This indicates that the manipulation of internal prices for tax reasons is primarily a phenomenon for large firms in tax havens. Further, we find that the relationship between pricing to market and internal prices is more prevalent in large firms.

In columns (3) and (4), we analyze another source of heterogeneity by operating a distinction across the nationality of ownership of a MNE. In column (3) we include MNEs that are French resident or owned at a majority by a French group (as well as all non-MNEs). In column (4), we include MNEs that are majority owned by a foreign group and all exporters.

\footnotetext{
${ }^{28}$ The sample consists of 45 countries. For this reason, some deciles have 5 countries and others have 4 countries.

${ }^{29}$ The estimated coefficients are obtained from a regression of export prices on the tax decile of the destination country and its interaction with a dummy equal to one if the price is intra-firm. The regression also includes firm-product-exporting mode fixed effects, and distance, GDP per capita, and tariffs and their interaction with the intra-firm dummy.

${ }^{30}$ Note that as all the estimations in Table 3 include destination fixed effects, only the interaction terms can be estimated.
} 
Figure 1: Non-linear effect of corporate tax rate on transfer pricing

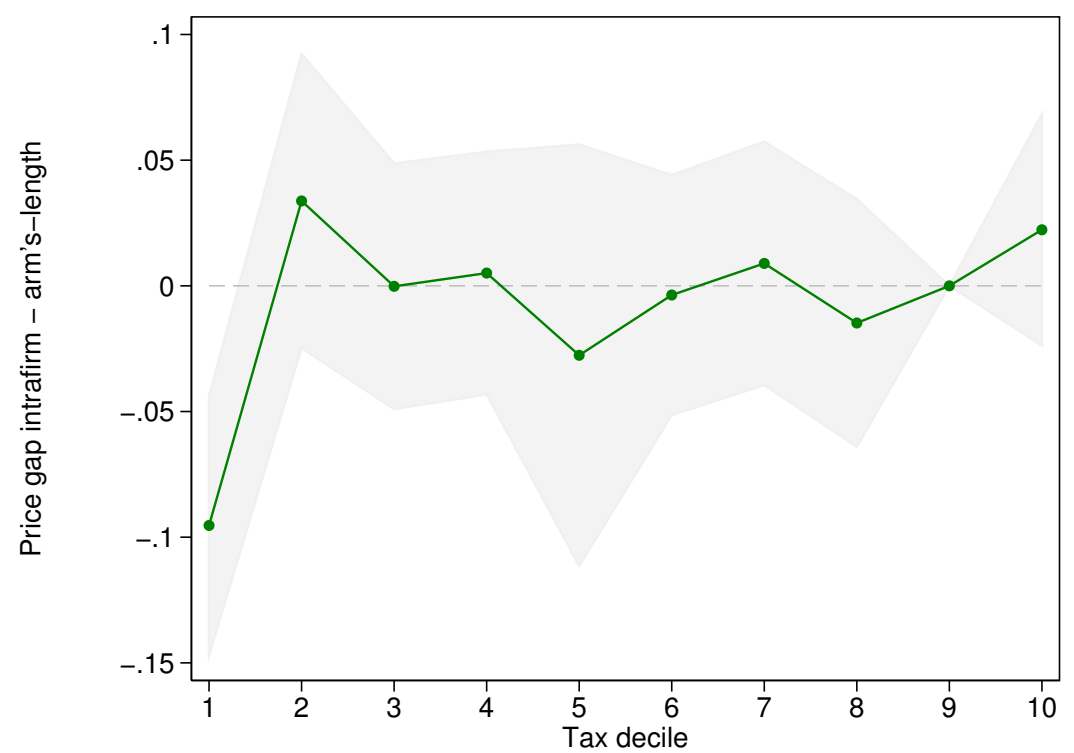

Note: This graph displays the price wedge between intra-firm and arm's length prices by decile of the destination country corporate tax rate. The price wedge is measured by the coefficients on the interaction between tax deciles and an intra-firm dummy in a regression of the logarithm of exports prices on firm-product-exporting mode fixed effects, tax decile of the destination country, GDP per capita, distance, and tariff, and their interaction with a dummy equal to one if the exports are between related parties. The first decile is the decile of countries with the lowest corporate tax rates. The tenth decile is the decile with the highest corporate tax rates. Decile 9 is normalized to zero (countries with the same level of tax as France). The gray area corresponds to the confidence interval at $5 \%$.

Comparing the two, we find that the coefficients are estimated more precisely in the French firms' sample. In particular, we find the effective marginal tax rate to have a strong, negative and significant impact on the log level intra-firm export prices. A comparable effect is found for tax havens. These results therefore again suggest that tax havens are playing a major role in the transfer pricing strategies of French firms. In column (4), although the sign of the tax rate and tax haven variables match those in the French-only sample, the significance of both is much lower with only the tax haven variable significant at the $5 \%$ level. This suggests that similar forces are at play for this sample as well, although there may be greater noise introduced due to the variety of parent countries in this sample as compared to that in column (3). In particular, if the MNEs from other countries face worldwide taxation (as do the U.S. firms in Bernard et al. (2006)), this may illustrate the cleaner tax effects to be found by using data on FDI from a tax-exempting country. 


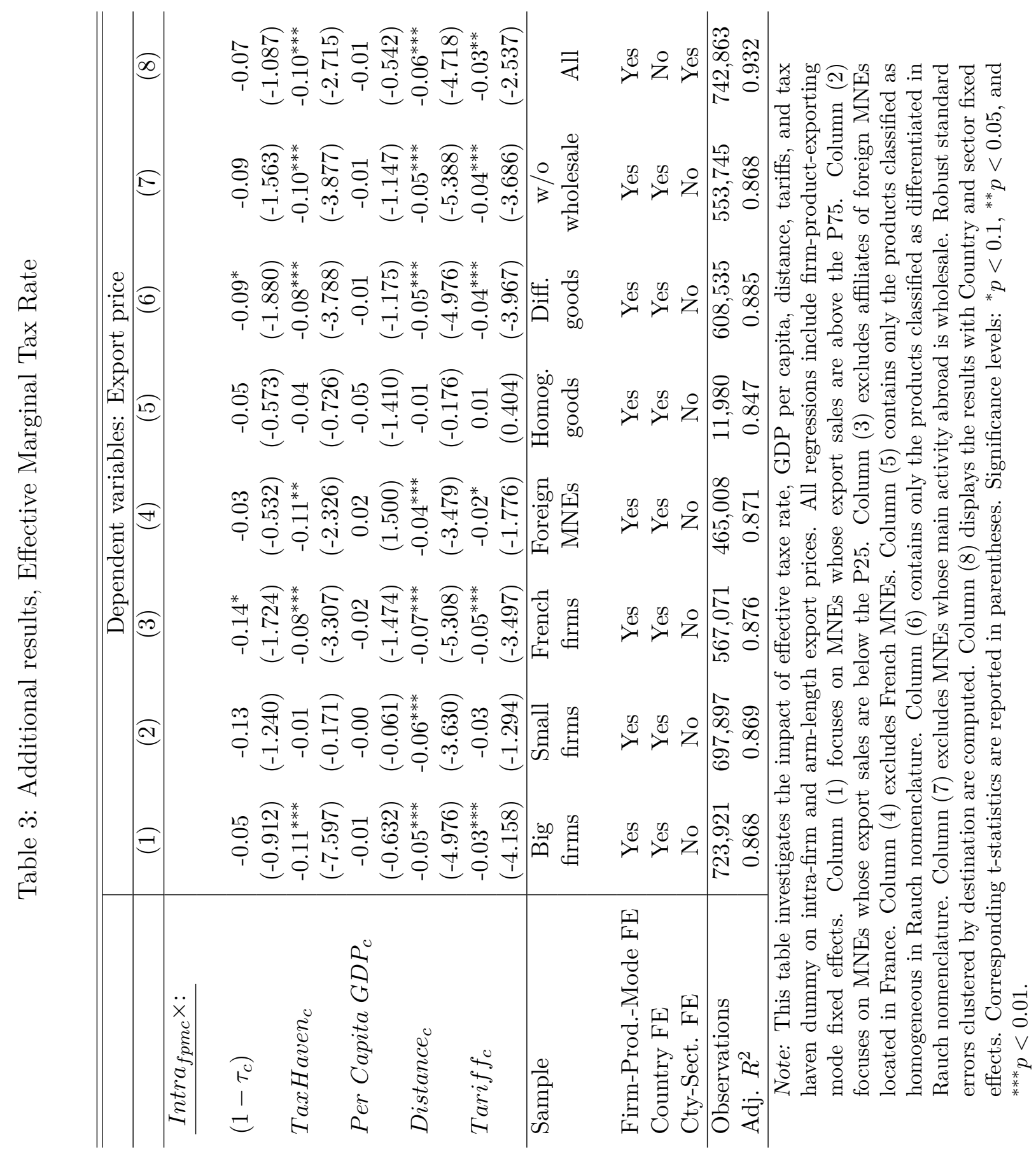


In France, as in most countries, the tax authority's expectation is that firms set the price of their internal transactions according to the arm's length principle. ${ }^{31}$ The main force at play in the above model is that deviations from this price come at a cost. This cost includes penalties incurred if a firm were caught out. When the appropriate arm's length price is easily determined, as is the case for homogeneous goods that are traded on organized exchange, transfer pricing should therefore be minimal. In contrast, differentiated products that are by definition specific to the relationship lack such comparable arm's length transactions (Blonigen et al. 2014). Thus, MNEs that are exporting differentiated products might more easily reduce taxes via transfer pricing. ${ }^{32}$ In columns (5) and (6), we use the Rauch (1999) classification and document the effect of taxes and tax havens on both the homogenous and the differentiated goods category. Goods that are exchanged on organized markets, i.e. where appropriate prices are easily verified by tax authorities, show no differences between intraand extra-firm transactions. Differentiated products, on the other hand, do show evidence of such. Notice that the estimated coefficient reported in column (6) are in line with the one found in the baseline estimation (Column (6) of Table 2).

In column (7), we show that our baseline result are robust to the exclusion of the observations of firms active in the wholesale sectors as the pricing behavior of such firms may differ from that of others. As can be seen, the results are robust to their exclusion.

Last, we deal with the self-selection of firms into the multinational status. As emphasized by Helpman et al. (2004), the selection of firms into multinationals depends upon a set of firm characteristics and on barriers to entry and other destination market characteristics such as the level of competition. These characteristics may well be influenced by the corporate tax rate or the tax haven status of the destination market. Our specification allows for the possibility that market characteristics vary across industries and across countries. ${ }^{33}$ In column $(8)$, we include country $\times$ HS1-industry fixed effects and show that our main results remain.

In table 7 of the appendix, we provide the estimates using the EATR variable. We find that our results are robust to the use of this alternative definition of the corporate tax rate.

Back-of-the-envelope calculation. To quantify the loss for tax authorities due to transfer pricing, we use the estimates of the baseline estimation, column (4). In our quantification exercise, we compute the loss of the exports due to lower pricing in tax havens. In 1999, the French effective corporate tax rate was 31.77 percent and brought in about 36 billion euros of corporate tax receipts. ${ }^{34}$

In column (3) of Table 2, we find that intra-firm prices are $10.4 \%$ (exp(-0.11)-1) lower

\footnotetext{
${ }^{31}$ This means applying prices that independent enterprises would set in identical transactions (B.O.I. 1999).

${ }^{32}$ Bernard et al. (2006) find that the difference between intra- and extra-firm prices is larger for differentiated goods than homogenous ones, however, they do not estimate how the effect of taxes impacts the price wedge across groups.

${ }^{33}$ In our model, it means that the demand shifter $A$ is country-product specific.

${ }^{34}$ http://www.performance-publique.budget.gouv.fr/farandole/archives/1999/lftab99.htm. Taxes are charged on the taxable income which consists of operational and financial profits minus charges.
} 
Table 4: Under-reporting to tax havens

\begin{tabular}{lccc}
\hline \hline Country & $\begin{array}{c}\text { Sh. French } \\
\text { exports }\end{array}$ & $\begin{array}{c}\text { Sh. exports } \\
\text { intra-firm }\end{array}$ & $\begin{array}{c}\text { Value not reported } \\
\text { (million euros) }\end{array}$ \\
\hline Switzerland & 0.0407 & 0.58 & 590.0 \\
Ireland & 0.0083 & 0.62 & 129.0 \\
Singapore & 0.0072 & 0.58 & 105.0 \\
Hong Kong & 0.0071 & 0.54 & 96.3 \\
Luxembourg & 0.0056 & 0.37 & 51.3 \\
Malta & 0.0019 & 0.88 & 42.3 \\
Cyprus & 0.0007 & 0.53 & 9.9 \\
Bermuda & 0.0003 & 0.85 & 5.9 \\
Bahamas & 0.0002 & 0.51 & 2.8 \\
Cayman Islands & 0.0001 & 0.55 & 0.7 \\
\hline
\end{tabular}

than the market price in tax havens. ${ }^{35}$ Table 4 reports the share of exports and the share of these that were intra-firm for the ten tax havens. As can be seen, three of these countries are important export destinations. Further, the shares of intra-firm exports to Switzerland and Ireland are very high (around 60\%). Using the intra-firm trade values in the data, the final column gives the value of under-priced intra-firm exports, the sum of which amounts to more than one billion euros. Without this under-reporting, French tax authorities would have collected 340 million euros more. This figure can be compared to the 36 billion euros collected in 1999 (which includes both services and manufacturing), meaning that total tax revenues in that year would have been roughly $1 \%$ greater were it not for transfer pricing by manufacturing firms in these ten tax havens. ${ }^{36}$ Interestingly, only 2,495 firms make intra-firm exports to these countries with a scant 450 firms accounting for $90 \%$ of intra-firm exports to these ten countries. More so, almost $50 \%$ of intra-firm exports to these tax haven destinations are done by 25 firms. This suggests that a small number of firms are avoiding a large tax payment. This is an important factor to acknowledge as the OECD's (2012) survey of tax authorities finds that the cost of pursuing transfer pricing MNEs is of major concern.

Our results suggest that the lion share of transfer pricing practices in France is concentrated in the exports to at most ten countries by about $7 \%$ of multinationals. Targeting exports by these firms to tax havens would make enforcement of the arm's length price principle more efficient.

\section{Conclusion}

Despite the clear incentive firms have to shift profits through transfer pricing and the widespread concern over its implications, direct and systematic evidence of this practice

\footnotetext{
${ }^{35}$ We consider all intra-firm exports not only the ones used in our estimates.

${ }^{36}$ Note that this number does not consider any transfer pricing in the services sector for these countries.
} 
remains scarce. This is due to a general lack of data on the prices used within a multinational and the prices for comparable arm's length transactions. Thus, the importance of transfer pricing practices in terms of monetary value and of number of firms and countries involved remains largely unanswered.

We have built a unique dataset that overcomes this problem. These data contain prices at the firm-product-destination level for both intra-firm and arm's length exports. This level of data is important for three key reasons. First, it allows us to control for other determinants of prices across firms, such as the relative productivity of multinationals as compared to exporters. Second, it allows us to control for the destination country's characteristics, such as income and trade costs, which are potentially correlated with tax variables yet impact intra-firm and arm's length prices in different ways. Third, the richness of the data allows us to consider not only the effect of foreign corporate taxes on pricing behavior, but also the role of tax havens and how this behavior varies with firm and product characteristics.

We find that internal prices are lower in destinations with lower tax rates and most importantly in tax havens. Furthermore, transfer pricing is primarily found within large MNEs. These results are crucial for two reasons. First, they support the OECD's (2013) assertion that there is a difference between low-tax countries and tax havens which provide a tax environment particularly amenable to tax avoidance. Second, it shows that although transfer pricing may result in significant revenue losses, such losses are primarily due to a small number of firms. Given that our estimates are for 1999 alone, the cumulative tax losses from such transfer pricing should be quite large. This implies that by appropriately targeting enforcement, a significant increase in revenues may be achieved at a small cost. Moreover, since our data is only for manufacturing, and not services, this tax loss is likely just the tip of the iceberg.

\section{References}

Atalay, E., Hortacsu, A. \& Syverson, C. (2014), 'Vertical integration and input flows', American Economic Review 104(4), 1120-48.

Bartelsman, E. J. \& Beetsma, R. M. W. J. (2003), 'Why pay more? Corporate tax avoidance through transfer pricing in OECD countries', Journal of Public Economics 87(9-10), 22252252 .

Bastos, P. \& Silva, J. (2010), 'The quality of a firm's exports: Where you export to matters', Journal of International Economics 82(2), 99-111.

Becker, J. \& Davies, R. B. (2014), A Negotiation-Based Model of Tax-Induced Transfer Pricing, mimeo.

Behrens, K., Peralta, S. \& Picard, P. M. (2009), Transfer Pricing Rules, OECD Guidelines, and Market Distortions, Cahiers de recherche 0943, CIRPEE. 
Berman, N., Martin, P. \& Mayer, T. (2012), 'How do Different Exporters React to Exchange Rate Changes?', The Quarterly Journal of Economics 127(1), 437-492.

Bernard, A. B., Jensen, J. B. \& Schott, P. K. (2006), Transfer Pricing by U.S.-Based Multinational Firms, NBER Working Papers 12493, National Bureau of Economic Research, Inc.

Blonigen, B. A., Oldenski, L. \& Sly, N. (2014), 'Separating the Opposing Effects of Bilateral Tax Treaties', American Economic Journal: Economic Policy 6(2), 1-18.

B.O.I. (1999), Bulletin Officiel des Impots/Official Tax Bulletin, general tax directorate, Technical report.

Clausing, K. A. (2003), 'Tax-motivated transfer pricing and US intrafirm trade prices', Journal of Public Economics 87(9-10), 2207-2223.

Cristea, A. D. \& Nguyen, D. X. (2014), Transfer Pricing by Multinational Firms: New Evidence from Foreign Firm Ownerships, mimeo.

Dharmapala, D. \& Hines, J. R. (2009), 'Which countries become tax havens?', Journal of Public Economics 93(9-10), 1058-1068.

Dharmapala, D. \& Riedel, N. (2013), 'Earnings shocks and tax-motivated income-shifting: Evidence from European multinationals', Journal of Public Economics 97(C), 95-107.

Diewert, E., Alterman, W. \& Eden, L. (2006), Transfer Prices and Import and Export Price Indexes: Theory and Practice, in 'Price and Productivity Measurement', Trafford Press, W. Erwin Diewert, Bert M. Balk, Dennis Fixler, Kevin J. Fox and Alice O. Nakamura.

Ernst \& Young (2012), Transfer pricing global reference guide, Ernst and Young.

Fuest, C., Huber, B. \& Mintz, J. (2003), Capital Mobility and Tax Competition: A Survey, CESifo Working Paper Series 956, CESifo Group Munich.

Goldberg, L. S. \& Campa, J. M. (2010), 'The Sensitivity of the CPI to Exchange Rates: Distribution Margins, Imported Inputs, and Trade Exposure', The Review of Economics and Statistics 92(2), 392-407.

Gresik, T. A. (2001), 'The Taxing Task of Taxing Transnationals', Journal of Economic Literature 39(3), 800-838.

Gumpert, A., Hines, J. R. \& Schnitzer, M. (2011), The Use of Tax Havens in Exemption Regimes, NBER Working Papers 17644, National Bureau of Economic Research, Inc.

Haufler, A. \& Schjelderup, G. (2000), 'Corporate tax systems and cross country profit shifting', Oxford Economic Papers 52(2), 306-25. 
Heckemeyer, J. H. \& Overesch, M. (2013), Multinationals' profit response to tax differentials: Effect size and shifting channels, ZEW Discussion Papers 13-045, ZEW - Zentrum fÃijr EuropÃdische Wirtschaftsforschung / Center for European Economic Research.

Helpman, E., Melitz, M. J. \& Yeaple, S. R. (2004), 'Export Versus FDI with Heterogeneous Firms', American Economic Review, American Economic Association 94(1), 300-316.

Hines, J. R. \& Rice, E. M. (1994), 'Fiscal Paradise: Foreign Tax Havens and American Business', The Quarterly Journal of Economics 109(1), 149-82.

Huizinga, H. \& Laeven, L. (2008), 'International profit shifting within multinationals: A multi-country perspective', Journal of Public Economics 92(5-6), 1164-1182.

Kant, C. (1988), 'Endogenous transfer pricing and the effects of uncertain regulation', Journal of International Economics 24(1-2), 147-157.

Keuschnigg, C. \& Devereux, M. P. (2013), 'The arm's length principle and distortions to multinational firm organization', Journal of International Economics 89(2), 432-440.

Loretz, S. (2008), 'Corporate taxation in the OECD in a wider context', Oxford Review of Economic Policy 24(4), 639-660.

Manova, K. \& Zhang, Z. (2012), 'Export prices across firms and destinations', The Quarterly Journal of Economics 127(1), 379-436.

Martin, J. (2012), 'Markups, quality, and transport costs', European Economic Review 56(4), 777-791.

Mayer, T. \& Zignago, S. (2006), Notes on cepii's distances measures, MPRA Paper 26469, University Library of Munich, Germany.

OECD (2000), Towards Global Tax Cooperation.

OECD (2010), OECD Transfer Pricing Guidelines for Multinational Enterprises and Tax Administrations.

OECD (2012), Dealing Effectively with the Challenges of Transfer Pricing.

OECD (2013), Action Plan on Base Erosion and Profit Shifting.

Overesch, M. (2006), Transfer pricing of intrafirm sales as a profit shifting channel: evidence from German firm data, ZEW Discussion Papers 06-84, ZEW - Zentrum fÃijr EuropÃdische Wirtschaftsforschung / Center for European Economic Research.

Ramondo, N., Rappoport, V. \& Ruhl, K. J. (2011), Horizontal vs. vertical fdi : Revisiting evidence from u.s. multinationals, Working Papers 11-12, New York University, Leonard N. Stern School of Business, Department of Economics. 
Rauch, J. E. (1999), 'Networks versus markets in international trade', Journal of International Economics 48(1), 7-35.

Simonovska, I. (2010), Income differences and prices of tradables, NBER Working Papers 16233, National Bureau of Economic Research, Inc.

Swenson, D. L. (2001), 'Tax reforms and evidence of transfer pricing', National Tax Journal 54(n. 1), 7-26.

Vicard, V. (2014), Transfer pricing of multinational companies and aggregate trade, mimeo.

Zucman, G. (2014), 'Tax Evasion on Offshore Profits and Wealth', Journal of Economic Perspectives, (forthcoming). 


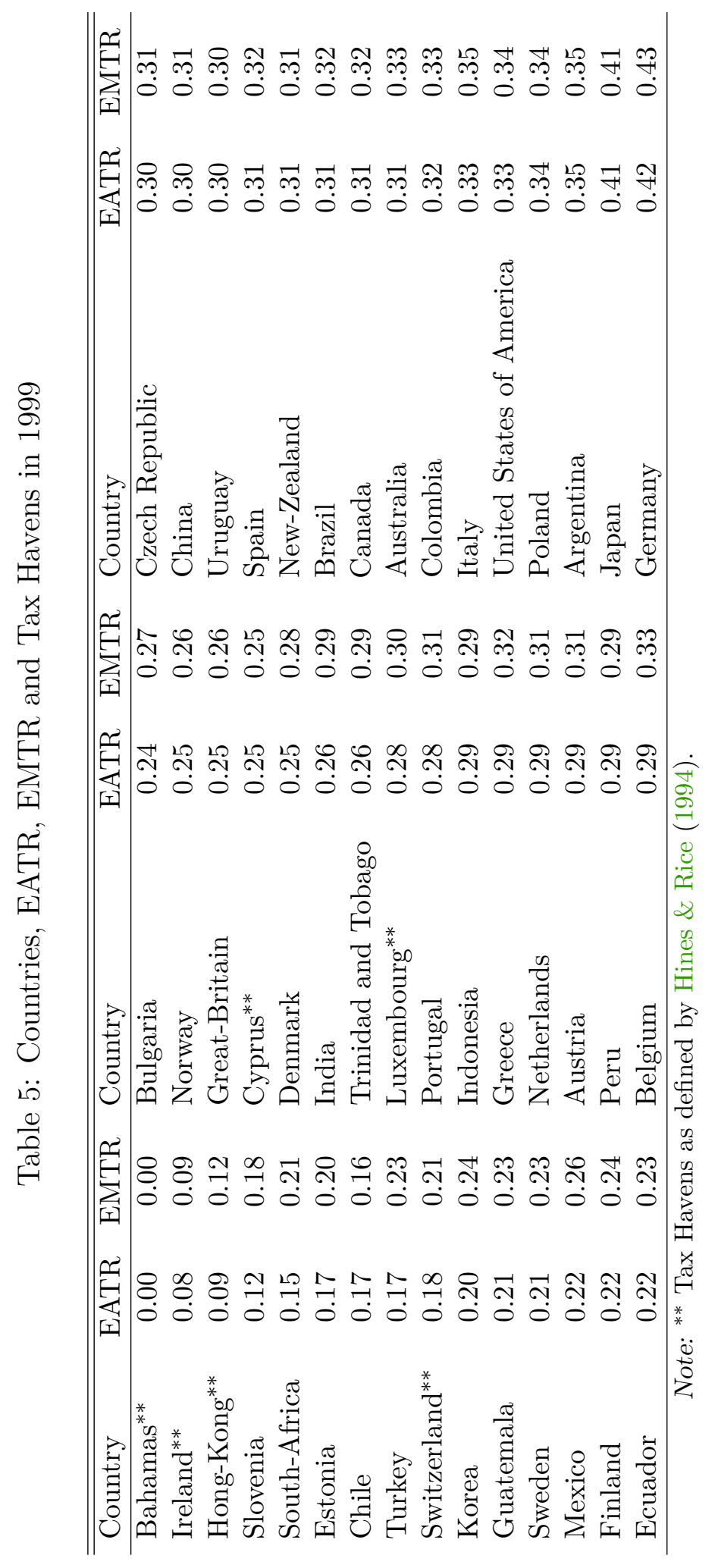


Table 6: Baseline regression Effective Average Tax Rate, All firms

\begin{tabular}{|c|c|c|c|c|c|c|}
\hline & \multicolumn{6}{|c|}{ "Dependent variables: Export price } \\
\hline & $(1)$ & (2) & $(3)$ & (4) & $(5)$ & $(6)$ \\
\hline$\left(1-\tau_{c}\right)$ & $\begin{array}{c}0.12 \\
(0.870)\end{array}$ & $\begin{array}{c}0.12 \\
(0.847)\end{array}$ & & $\begin{array}{c}-0.02 \\
(-0.211)\end{array}$ & $\begin{array}{c}-0.04 \\
(-0.419)\end{array}$ & \\
\hline$-\times \operatorname{Intra}_{f p m c}$ & $\begin{array}{l}-0.22^{* *} \\
(-2.277)\end{array}$ & $\begin{array}{c}-0.22^{*} \\
(-1.994)\end{array}$ & & $\begin{array}{c}-0.11 \\
(-1.590)\end{array}$ & $\begin{array}{c}-0.06 \\
(-1.248)\end{array}$ & $\begin{array}{c}-0.08 \\
(-1.253)\end{array}$ \\
\hline TaxHaven $_{c}$ & & & $\begin{array}{c}0.11 \\
(1.574)\end{array}$ & $\begin{array}{c}0.12 \\
(1.561)\end{array}$ & & \\
\hline$-\times \operatorname{Intra} a_{f p m c}$ & & & $\begin{array}{l}-0.11^{* *} \\
(-2.686)\end{array}$ & $\begin{array}{l}-0.09^{* *} \\
(-2.346)\end{array}$ & & $\begin{array}{l}-0.09^{* * *} \\
(-2.795)\end{array}$ \\
\hline Per Capita $G D P_{c}$ & & $\begin{array}{l}-0.03^{* *} \\
(-2.636)\end{array}$ & $\begin{array}{c}-0.01 \\
(-1.108)\end{array}$ & $\begin{array}{c}-0.01 \\
(-1.178)\end{array}$ & $\begin{array}{l}-0.02^{*} \\
(-1.715)\end{array}$ & $\begin{array}{c}-0.00 \\
(-0.390)\end{array}$ \\
\hline$-\times \operatorname{Intra} a_{f p m c}$ & & $\begin{array}{l}-0.03^{* * *} \\
(-3.269)\end{array}$ & $\begin{array}{c}-0.01 \\
(-1.138)\end{array}$ & $\begin{array}{c}-0.01 \\
(-1.320)\end{array}$ & $\begin{array}{l}-0.02^{*} \\
(-2.024)\end{array}$ & $\begin{array}{c}-0.01 \\
(-0.628)\end{array}$ \\
\hline Distance $_{c}$ & & $\begin{array}{l}0.08^{* * *} \\
(2.849)\end{array}$ & $\begin{array}{l}0.08^{* * *} \\
(3.631)\end{array}$ & $\begin{array}{l}0.08^{* * *} \\
(3.651)\end{array}$ & $\begin{array}{l}0.11^{* * *} \\
(4.301)\end{array}$ & \\
\hline$-\times \operatorname{Intra} a_{f p m c}$ & & $\begin{array}{l}-0.04^{* * *} \\
(-2.806)\end{array}$ & $\begin{array}{l}-0.05^{* * *} \\
(-4.811)\end{array}$ & $\begin{array}{l}-0.05^{* * *} \\
(-4.440)\end{array}$ & $\begin{array}{l}-0.06^{* * *} \\
(-4.961)\end{array}$ & $\begin{array}{l}-0.05^{* * *} \\
(-4.151)\end{array}$ \\
\hline Tarif $f_{c}$ & & $\begin{array}{c}0.03 \\
(1.056)\end{array}$ & $\begin{array}{c}0.03 \\
(1.122)\end{array}$ & $\begin{array}{c}0.03 \\
(1.165)\end{array}$ & $\begin{array}{c}0.01 \\
(0.425)\end{array}$ & \\
\hline$-\times \operatorname{Intra} a_{f p m c}$ & & $\begin{array}{c}-0.03^{*} \\
(-1.986)\end{array}$ & $\begin{array}{l}-0.03^{* *} \\
(-2.617)\end{array}$ & $\begin{array}{l}-0.03^{* *} \\
(-2.397)\end{array}$ & $\begin{array}{c}-0.02 \\
(-1.596)\end{array}$ & $\begin{array}{l}-0.03^{* * *} \\
(-3.125)\end{array}$ \\
\hline Sample & Full & Full & Full & Full & w.o Tax H. & Full \\
\hline Country FE & No & No & No & No & No & Yes \\
\hline Firm-Prod.-Mode FE & Yes & Yes & Yes & Yes & Yes & Yes \\
\hline $\begin{array}{l}\text { Observations } \\
\text { Adj. } R^{2}\end{array}$ & $\begin{array}{c}756,332 \\
0.862\end{array}$ & $\begin{array}{c}735,064 \\
0.865\end{array}$ & $\begin{array}{c}735,064 \\
0.865\end{array}$ & $\begin{array}{c}735,064 \\
0.865\end{array}$ & $\begin{array}{c}657,117 \\
0.870\end{array}$ & $\begin{array}{c}735,064 \\
0.866\end{array}$ \\
\hline
\end{tabular}

Note: This table investigates the impact of effective taxe rate, GDP per capita, distance, tariffs, and tax haven dummy on intra-firm and arm-length export prices. Effective tax rates are transformed as follows: $(\log (1-\tau))$. All regressions include firm-product-exporting mode fixed effects. The last column further includes country fixed effects. In column (5) we restrict the sample to countries not classified as tax havens. Robust standard errors clustered by destination are computed. Corresponding t-statistics are reported in parentheses. Significance levels: ${ }^{*} p<0.1,{ }^{* *} p<0.05$, and ${ }^{* * *} p<0.01$. 


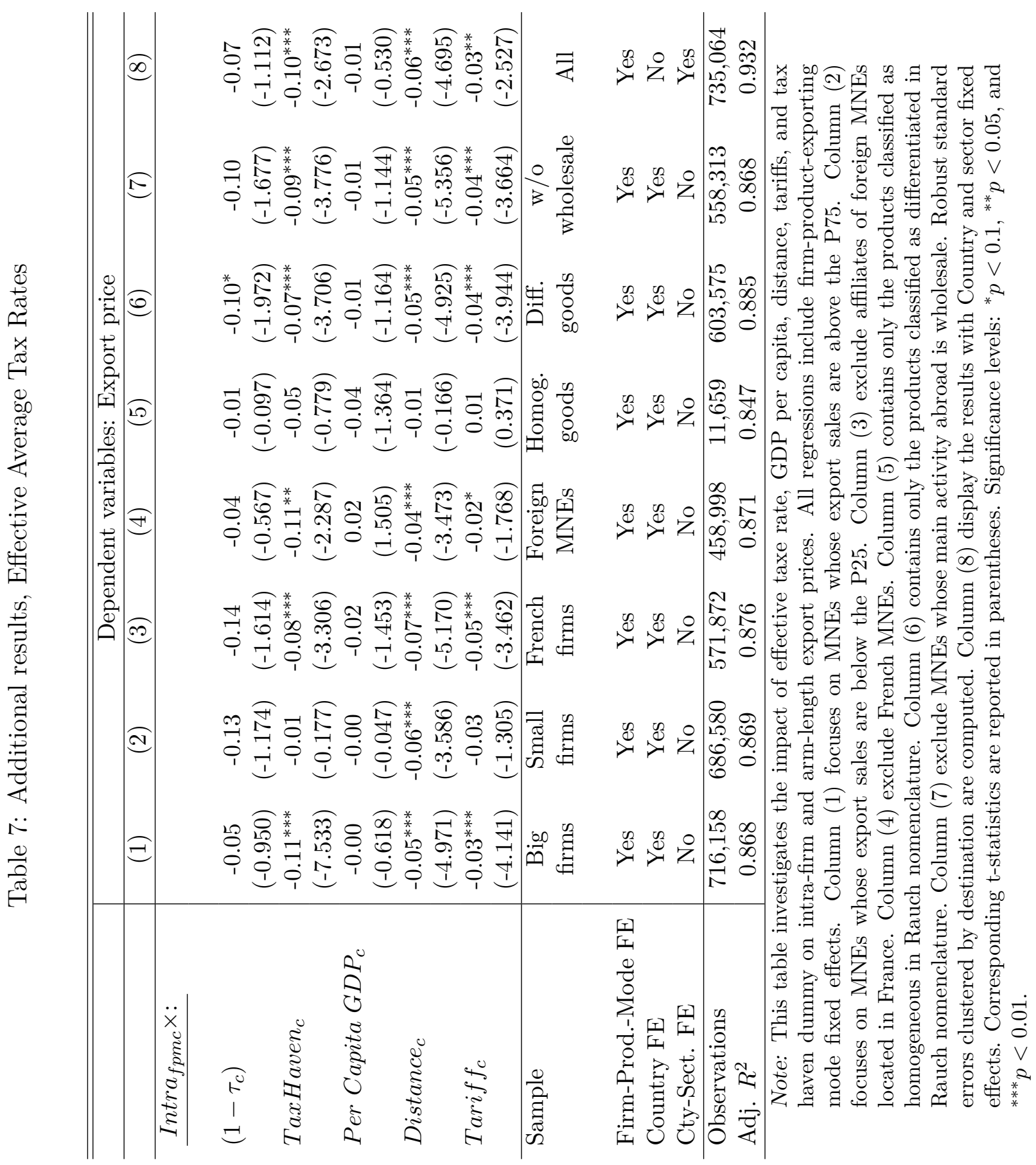

